University of Nebraska - Lincoln

DigitalCommons@University of Nebraska - Lincoln

Faculty Publications: Department of Entomology

Entomology, Department of

2009

Using the World Wide Web to Educate and Inform the Public about Risk and Agricultural Biotechnology

Douglas A. Golick

University of Nebraska-Lincoln, dgolick2@unl.edu

Robert D. Peterson

Montana State University - Bozeman, padr20@yahoo.com

Leon G. Higley

University of Nebraska-Lincoln, Ihigley1@unl.edu

Follow this and additional works at: https://digitalcommons.unl.edu/entomologyfacpub

Part of the Agribusiness Commons, Agricultural Education Commons, Biotechnology Commons, Community-Based Learning Commons, Educational Methods Commons, Environmental Health

Commons, and the Risk Analysis Commons

Golick, Douglas A.; Peterson, Robert D.; and Higley, Leon G., "Using the World Wide Web to Educate and Inform the Public about Risk and Agricultural Biotechnology" (2009). Faculty Publications: Department of Entomology. 355.

https://digitalcommons.unl.edu/entomologyfacpub/355

This Article is brought to you for free and open access by the Entomology, Department of at DigitalCommons@University of Nebraska - Lincoln. It has been accepted for inclusion in Faculty Publications: Department of Entomology by an authorized administrator of DigitalCommons@University of Nebraska - Lincoln. 
Published in the Journal of Agricultural \& Food Information (2009) 10: 102-112. DOl: 10.1080/10496500902802726. Copyright 2009, Taylor \& Francis. Used by permission.

\section{Using the World Wide Web to Educate and Inform the Public about Risk and Agricultural Biotechnology Douglas A. Golick ${ }^{1}$, Robert K.D. Peterson ${ }^{2}$, and Leon G. Higley ${ }^{3}$}

${ }^{1}$ Instructional Development and Support, University of Kansas, Lawrence, Kansas, USA ${ }^{2}$ Department of Land Resources and Environmental Sciences, Montana State University, Bozeman, Montana, USA

${ }^{3}$ Department of Entomology, University of Nebraska-Lincoln, Lincoln, Nebraska, USA

The University of Nebraska and AgBios, Inc. launched the AgBiosafety website (http://agbiosaftzy.unl.edu) with the purpose of educating the public about agricultural biotechnology risk and safezy issues through science-based content. This article discusses the creation ofthe website, its components, and data gathered from usage statistics and a web-delivered survey. Also included is a discussion of the results ofdata gathered and recommendations for future web-based educational efforts in biotechnology safety and risk assessment.

Keywords: Agriculture education, Biotechnology safety, Risk communication, Risk education

\section{INTRODUCTION}

In recent years, one of the more publicly debated social issues has been the safety of biotech plants (i.e., genetically modified plants or genetically engineered plants). Plants derived from biotechnology contain foreign genes inserted through molecular techniques. In plant biotechnology, the goal of gene insertion is to change the plant so it produces a desired trait. Biotechnology has been used in agriculture to develop plants that resist insect pests, increase yield, tolerate drought, change the property of grain oils, improve shelf life, fortify nutritional content, and produce pharmaceuticals.

Although concerns and controversy over biotech crops often receive much publicity, the fact-based education efforts and research articles addressing the risk of biotech crops typically have received less attention.

The authors thank the Council of Biotechnology Information for providing funding for the AgBiosafety website. We also thank Steve Spomer at the University of Nebraska for his review of an earlier version of this manuscript.

Received December 7, 2008; accepted January 14, 2009. Address correspondence to Dr. Douglas A. Golick, University of Nebraska-Lincoln, Lincoln, Nebraska, USA. E-mail: dgolick2@unl.edu. 
Experts have suggested that the media plays a role in public perceptions, especially in reinforcing attitudes about agricultural biotechnology (Vestal \& Briers, 2000). Most of the public receives their information about biotechnology from mass media (Vestal \& Briers, 2000; Zechendorf, 1994). Although journalists make an effort to be accurate in reporting, their knowledge of the science of biotechnology is limited (Vestal \& Briers). Further complicating public understanding of agricultural biotechnology safety is that people tend to build their beliefs and attitudes about the risk of biotechnology only on social, cultural, economic, and political issues rather than on science-based knowledge coupled with social considerations (Hagedorn \& Allender-Hagedorn, 1997; Peterson, 2000; Wolt \& Peterson, 2000).

The goal of biotechnology education for lay audiences should be for the public to make informed decisions about the safety of biotech crops. A key component to informed decisions about biotechnology is risk communication. A risk communication paradigm was outlined by the National Research Council (989). This paradigm provides an interactive model for communicating risks and opinions between individuals, groups, and institutions. Peterson and Higley (1993) adopted this model and proposed five principles for communicating risks about pesticides. Additionally, Peterson (2000) discussed the applicability of these principles to agricultural biotechnology. One of the principles is expert and institutional interaction in informing the public about risks. An essential component of agricultural biotechnology risk assessment is education. Especially important are efforts led by trusted public officials (Wolt \& Peterson, 2000). Therefore, the University of Nebraska and AgBios, Inc. launched the AgBiosafety website (http://agbiosafety.unl.edu) in September 2001, with the purpose of educating the public about agricultural biotechnology risk and safety issues through science-based content. Funding for the project was provided by the Council for Biotechnology Information, an agricultural industry-sponsored group. Because industry, rather than public funding, supported the project, clear barriers between sponsors and educational programs were established to avoid real or perceived bias. Specifically, content was prepared by experts with subsequent peer-review by scientific and educational reviewers. Additionally, sponsors had no opportunity to review or approve materials produced. Finally, continuations in funding were contingent on progress in developing educational materials, but (explicitly) not on the content or type of materials.

Despite these safeguards, there is an understandable public attitude that sources of funding necessarily bias outcomes in research or education programs. Experience with tobacco industry "scientists" denying the role of tobacco in causing lung cancer reinforces this perception. Because much criticism of biotechnology is not science-based, we knew that we 
had to develop educational programs on the scientific process and what constitutes scientific certainty and uncertainty. Thus, our educational goals from the outset had to be broader than focusing only on issues surrounding a specific technology in agriculture.

When biotech crops were first introduced, science and safety information was targeted toward agricultural audiences, with few efforts made towards nonagricultural audiences (Byrne et al., 2002). The World Wide Web provides a means of educating a large audience (millions have access to the Internet) on biotechnology safety issues. This article discusses the AgBiosafety website, the data gathered from usage statistics, and a webdelivered survey.

\section{THE WEBSITE}

The AgBiosafety website is a collaborative effort between the University of Nebraska-Lincoln and AgBios, Inc., a regulatory consulting company based in Merrickville, Ontario. The website's primary goal is to educate the public on agricultural biotechnology safety issues through sciencebased content. Through these educational materials, the long-term goal of AgBiosafety is to help the target audience (consumers, teachers, students, and members of the media) make informed opinions about biotech safety issues. Because many people have strong opinions about biotech safety, much effort was put into creating objective content, i.e., it did not promote or discourage the use of biotech crops. The AgBiosafety website is composed of three parts: the Education Center, Questions Answered Section, and a Database of Regulatory Information compiled and hosted by AgBios, Inc. (http://www.agbios.com/dbase.php). The focus of this paper is on the Education Center and the Questions Answered sections of the site. These sections contained lesson plans, topical papers, interactive education exercises; and articles on risk, risk assessment, risk perception, risk management, and the scientific method. The target audience for the website was broad, ranging from those highly informed on biotech safety issues, such as agricultural industry and post-secondary educators, to the less informed, such as K-12 students and the general public. Given the multiple target audiences, we put much effort into making the content accessible. An instructional designer, a high school teacher, and a community college instructor were hired to evaluate the content level of website materials. These evaluations were important in adjusting the level of content to ensure that it was accessible to specific audiences. Further, materials were customized for different levels of understanding by creating multiple versions of content for the different target groups.

The AgBiosafety site was advertised through agricultural biotech websites, through e-mails to known college educators in the biotech field, and to local high schools. Additionally, a press release was issued from the 
University of Nebraska announcing the launch of the site. Agbiosafety was also linked to several other biotech education websites. While the purpose of the site was to reach a broad audience, including K-12 audiences, due to a limited advertising budget, AgBiosafety was not specifically advertised in K-12 science or agricultural education journals.

\section{WEBSITE SECTIONS \\ Education Center}

The Education Center contains materials for use by elementary through introductory college-level students, organized both topically and by instruction type, as shown in Table 1 . Lesson plans were developed by the authors of this paper, with input from high school and college science educators. These lessons could be downloaded for printing and contained detailed instructions for conducting the lesson in the classroom. The goal of these lessons is to teach key concepts in crop biotechnology safety. Another focus of the Education Center is on interactive educational exercises for teaching biotech safety issues too difficult to show through lesson plans or in articles. Interactive exercises focused on teaching resistance management for insect resistant crops that produce Bacillus thuringiensis $(B t)$. Resistance management in $B t$ crops usually involves planting a percentage of non- $B t$ refuge crop ( $20 \%$ or greater) to suppress $B t$-resistant populations of European corn borers. The Resistance Evolution Simulation, shown in Figure 1, demonstrates population dynamics of European corn borers by allowing users to manipulate variables including size of refuge crops, number of resistant alleles, and the migration of adults to other fields. Once user input is received, the simulation calculates mortality and tracks gene makeup of corn borers over subsequent generations. Interactive exercises are an important part of the AgBiosafety site, as they provide immediate feedback to users.

Table 1 AgBiosafety Lesson Plans

Lesson Topic

Case Study in Bt Corn Pollen and the Monarch Butterfly

Creating a Transgenic Plant Pamphlet

Designing a New Genetically Engineered

Target Audience

(Grades)

10-college

4-12

$3-12$

Food Product

Designing a System to Ensure GE AG Safety

Position Paper on GE Safety

Resistance vs. Susceptibility Exercise

Student Created Survey on Genetically

Engineered Crop Safety Issues

Student Debate on the Risk of Bt Corn to

Monarch Butterflies 11-college

10-college

7-college

8-college

8-college 


\section{Beginning of Year 1}

Choose how you would like to plant your crops this year. When you are done, click "Begin year."

\section{What line of crops?}

Bt corn seed is awailable in two general categories: high dose Bt and medium dose Bt Choose which type.

6 High dose

$r$ Medium dose

\section{Spray pesticide?}

If you wish, you may spray pesticide on the non-Bt corn refuge.

6 Dont spray

$r$ Spray

\section{How much refuge?}

By law, you are required to plant a minimum of $20 \%$ "refuge" (non-Bt) crops. However, in this simulation, you can plant any amount you wish as non-Bt crops.

Refuge: $\quad 20 \% \quad 4$

Figure 1 Screen from $B t$ Resistance Management Simulation, an interactive exercise. Reproduced with permission.

\section{Questions Answered}

This section contains articles addressing biotech risk issues, with the goal of informing the audience about what risk is, how risk is assessed, how people perceive risk, and how regulatory decision makers manage risks. These articles, listed in Table 2, communicate risk issues to a lay audience by showing how science and risk assessment work. Articles provide visitors background on how scientists assess human and ecological risk and make decisions about risk. Even though the articles focus on risks and biotech crops, they are broadly applicable to all technologies.

\section{MEASURING IMPACT}

As materials were developed and posted on the website, we used multiple methods for testing and refining materials. First, peer-review provided a mechanism for ensuring accuracy. Second, materials were evaluated by educational experts on criteria that included age appropriateness, usefulness in the classroom, suitability to teaching objectives (both regarding biotechnology and science literacy), and an understanding of risk. Finally, as exercises were used in various formal and informal teaching settings, feedback from these experiences helped us determine if educational goals of the project were being met.

Broader evaluations of the effectiveness of web-based teaching materials are challenging because of the diversity of potential users and because their use depends upon teachers and students finding materials and determining that materials meet their needs. Almost any approach for mea- 
Table 2 Questions Answered from the AgBiosafety Website

Articles

WHY SCIENTISTS CAN NEVER PROVE THAT BIOTECH CROPS ARE SAFE

How Does Science Work?

I DON'T CARE WHAT THE SCIENTISTS SAY BIOTECH CROPS ARE TOO RISKY

Risk as Perception

HOW BAD TIMES HOW OFTEN

Risk as Science

I KNOW WHAT RISK IS, BUT HOW DO I ASSESS IT?

The Risk Assessment Paradigm

The Benefits and Risks of Producing Pharmaceutical Proteins in Plants

IS THAT STUFF SAFE TO EAT?

How Foods from Biotech Crops Are Evaluated for Human Safety

WILL THIS STUFF HARM THE ENVIRONMENT?

How Biotech Crops Are Evaluated for Environmental Safety in the United States

Does the Use of Herbicide-Resistant Crops Create Super Weeds

Do Bt Crops Harm Monarch Butterflies?
Category
Risk and Biotech Crops

Risk and Biotech Crops

Risk and Biotech Crops

Risk and Biotech Crops

Biopharmaceuticals

Food Safety

Environmental Safety

Environmental Safety

Environmental Safety

suring the effectiveness of stand-alone (outside of supervised instruction), web-based educational content is open to legitimate criticism or multiple interpretations. Consequently, we used multiple methods to assess educational usefulness. Specifically, to evaluate the effectiveness of the AgBiosafety site in reaching its educational goals - to educate the public on agricultural biotechnology safety issues and to help the target audience (consumers, teachers, students, and members of the media) make informed opinions about biotech safety issues - we used three sources of measurement: web usage statistics, visitor feedback, and web survey responses.

To determine if we reached our target audience, we examined site usage statistics. Web usage statistics were recorded for the University of Nebraska-Lincoln (UNL) portion of AgBiosafety with Network Solutions ${ }^{\circledR}$ SuperStats Web usage statistics compiler (http:/ / www.mycomputer. com) and server-based log stats. In the period beginning September 2001 through September 2008, there were 189,752 unique visitors, with an average of 2,258 unique visitors per month. In the same period, there were 304,179 visits (both unique and return), with an average of 3621.1 total visits per month. There was a return visitor retention rate of $37.6 \%$ (visitors that return to the site at least once). Since the launch of the site, there have been 643,531 page views, with an average of 7,661 page views per month. An average visit was composed of 2.1 page views. The Agbiosafety site has been linked to from 111 separate websites (Google search, September 20, 2008). 
To provide insight about the organizational affiliation of Agbiosafety visitors, we recorded the IP registration of our visitors. A total of $36.6 \%$ of visitor IP addresses were unidentified (IP address only), $25.0 \%$ commercial, 20.9\% from U.S. post-secondary and K-12 educational institutions, $15.8 \%$ from within the University of Nebraska system, $1.0 \%$ U.S. government, and $0.7 \%$ U.S. military. The user breakdown is $46.5 \%$ with IP addresses originating from the United States, 16.5\% from Canada, 7\% from the United Kingdom, 3\% from Australia, and the remainder from other countries (27\%). To date, persons with IP addresses originating in 96 countries have visited AgBiosafety.

Visitor feedback and comments concerning AgBiosafety were also collected through a web form. This form was accessible to visitors via a hyperlink posted on the Education Center and Questions Answered sections of the website. The purpose of the web form was to allow open-ended feedback about the site during the first year. Users were able to enter their contact information and leave comments about the site in the text-area provided. Upon completion of the web form, comments were e-mailed to us. These comments were useful in helping coordinators address technical problems, attend to content concerns, receive feedback about the quality of content, and address requests for use of content on other websites. Information collected also was helpful to AgBiosafety partners in steering the direction of the website in terms of what services and content to provide during the development phase of the project. Feedback received could be put into three general categories: emotive, request for use, and quality of site. Although emotive feedback concerning the content or purpose of the site was received throughout the period of the project, most emotive comments were received during the first year (75\%). Comments ranged from concerns about public institutions' role in biotech safety information to displeasure and fear of biotechnology. We addressed emotive concerns by sending visitors links or references to further information on the topic. Several requests for use of content were received during the project.

Generally, use of content on the UNL portion of the AgBiosafety site was permitted, as it was within the project's goals. Feedback concerning the quality of the site was also received. A majority of the content quality feedback (12 out of 15 comments) was positive in nature. Comments in this category were usually short, such as "good site." While information regarding the primary occupation of the user (i.e., our target audience) would have been helpful in tying this data to our outcomes, demographic information was not collected via the web form.

To collect additional data about the short- and potential long-term impact of the site on visitors, a web survey was used. The web survey was driven by Dragon Survey Software (http:/ / wmotion.com). With responses stored in a Filemaker Pro database (Filemaker, Inc.). The responses were recorded 
using a 5-point Likert scale ranging from strongly agree to strongly disagree. Site users were solicited for voluntary participation in the survey by means of a pop-up window on the site. Participants were allowed to answer the survey only once; multiple submissions from the same user were blocked via IP address exclusion provided by survey collection software. A total of 82 responses were collected during the survey period. The survey was composed of eight questions, including four demographic and four opinion questions. Participants were first asked their age and gender. The mean age was 37.5 years; $53.5 \%$ were female and $46.5 \%$ male. Participants were then asked their professional affiliation: $24.1 \%$ reported employment in post-secondary academic institutions, $20.9 \%$ as students, $18.9 \%$ in government agencies, $18.6 \%$ in private industry, $8 \%$ other, $4 \%$ in nongovernment associations, $3.5 \%$ in K-12 academic institutions, and 2\% in media. Participants were also asked to report the highest level of education attained: $60.5 \%$ held a graduate degree, $14 \%$ a 4 -year college degree, $14 \%$ a highschool diploma, $7 \%$ a pre-high school education, and $4.5 \%$ a 2 -year degree.

In addition to demographic information, opinion questions on the impact of the AgBiosafety site on the user's understanding of plant biotech safety and the quality of the website's content were also asked. We considered this the most important part of the survey, as it provided the best indication of whether the AgBiosafety site met its primary goals. Specifically, the survey was used to gather data on whether the AgBiosafety site had changed visitors' perception of biotech crop safety, whether respondents would use the site's educational resources for teaching, whether respondents learned something new about biotech safety, and whether they found the site content to be of high quality. Participant responses are shown in Table 3.

\section{DISCUSSION}

As a whole, we believe the AgBiosafety site has been effective in reaching a broad target audience, that the content of the website is of good quality,

Table 3 Participant Responses to AgBiosafety Website Survey: To What Degree Do You Agree or Disagree with the Following Questions?

\footnotetext{
Question

I have a more positive opinion in regards to the safety of biotech M SD crops as a result of the educational content of the AgBiosafety website. I will use educational materials found on AgBiosafety in teaching others about agricultural biotechnology safety issues. Content found on AgBiosafety has helped me learn something new about agricultural biotechnology safety. I would recommend AgBiosafety to someone else as a quality source of educational materials on agricultural biotechnology. $N=82$

Note. 1 = strongly agree, 2 = somewhat agree, $3=$ neither agree nor disagree, $4=$ somewhat disagree, $5=$ strongly diagree.
} 
and that its content is used for educational purposes. One of the goals of AgBiosafety was to reach a diverse audience. According to the webusage statistics and the survey, AgBiosafety has been successful in reaching a broad audience. The website was visited by persons working in postsecondary and K-12 institutions $(27.6 \%)$ and by students $(20.9 \%)$. The site also reached persons with a wide range of educational attainment, from those with graduate degrees $(60.5 \%)$ to those with a high-school degree or less $(21 \%)$.

Overall, survey participants thought the quality of the educational materials was good. Users generally agreed that they would recommend the site as a source of quality educational materials on agricultural biotechnology. Requests for permission to utilize materials served as a secondary indicator of the website's quality.

Before the launch of the website, we assumed that a large portion of the target audience would be laypersons. Therefore, there would be an opportunity to teach these persons something new about agricultural biotechnology safety. Data from the survey show a strong indication that participants thought the website taught them something new about agricultural biotech safety, even though $61 \%$ of those surveyed had graduate degrees.

Survey respondents somewhat agreed with the statement that they would use the materials for teaching others about biotech safety. This is likely due to the high number of individuals that reported their profession as being related to educational institutions (27.6\%). This is a positive outcome, as many of the resources on the website, including lesson plans and interactive modules, were intended for use in K-12 and college curricula.

One of the more interesting results from the survey came in response to the question concerning whether the website had a positive impact on the user's opinion on the safety of biotech crops. Survey results indicated that AgBiosafety likely had little or no positive impact on users' opinions on the safety of biotech crops. Although not a goal of the project, there is indication that the website did not affect a more positive audience opinion of biotech crops. Individual opinions on safety issues are usually based on deeply rooted social and emotive beliefs (Wolt \& Peterson, 2000). These beliefs are formed over a long time. Therefore, the ability of AgBiosafety and similar websites to change opinions regarding safety issues may be limited. It should be noted that results from this question should be carefully interpreted, as they do not indicate whether participants already had a very high or low opinion toward biotech crops prior to entering AgBiosafety. The intent of AgBiosafety was to provide objective science-based knowledge about biotechnology safety, not to promote or discourage its use in agriculture. With regard to this goal, the website has been successful in maintaining objectivity, as evidenced by the survey responses to the question concerning changes in positive opinions about biotech safety. 
Although AgBiosafety has successfully reached and exceeded its primary goal of educating the public on agricultural biotechnology safety issues through science-based content, we have some suggestions for future efforts. Although many unique persons visited AgBiosafety since its launch, only $37.6 \%$ came back to the site at least once. Therefore, future endeavors should find ways to retain visitors. One possible way to improve retention is to provide website visitors with the ability to subscribe to an e-mail list or use RSS feeds that would periodically inform them of new content postings and updates through e-mail. Ataminimum, this would remind visitors that the site is still in existence. One component of visitor retention is whether users employ the website only to address a specific question; if so, low return rates are to be expected. Similarly, if teachers download curricula or other materials for classroom use, there is little or no need to continue to visit the site.

Key questions that emerge from these observations are (a) how do people use educational/informational websites, and (b) is informational content most important or are opportunities for novel educational experiences more valuable? Although our site is information-rich regarding biotechnology, we also have five interactive programs. While the interactive programs themselves may focus on a single topic or theme, they provide an educational experience that is fundamentally different from a simple acquisition of technical information. The World Wide Web is ideally suited for both types of educational content, but its current educational use is primarily as a database (e.g., Google searches on topics). True interactivity involves changing a system in response to user decisions, and the value of interactivity is that it provides learning experiences unlike other approaches (Koster, 2005). With a topic as complex as the safety of biotechnology-which involves not only scientific understandings of the technology, but also legitimate economic, social, and political issues-presentation of facts alone is not sufficient. Consequently, we believe future efforts in education about biotechnology, its safety, and its risk assessment, should focus more on interactive learning experiences (whether web- or classroom-based) to better address the subtleties and interplay of all relevant scientific and social issues.

\section{REFERENCES}

Byrne, P.F., D.M. Namuth, J. Harrington, S.M. Ward, D. Lee, and P. Hain (2002). Increasing the public understanding of transgenic crops through the World Wide Web. Public Understanding of Science 11: 1-12. DOI: 10.1088/0963$6625 / 11 / 3 / 306$.

Hagedorn, C., and S. Allender-Hagedorn (1997). Issues in agricultural and environmental biotechnology: Identifying and comparing biotechnology issues from public opinion surveys, the popular press and technical/regulatory sources. Public Understanding of Science 6: 233-245. 
112 Golick, Peterson \& Higley in Journal of Agricultural \& Food Information (2009) 10:

Koster, R. (2005). A Theory of Fun for Game Design. Scottsdale, Ariz.: Paraglyph Press.

National Research Council. (1989). Improving Risk Communication. Washington, D.C.: National Academy Press.

Peterson, R.K.D. (2000). Public perceptions of agricultural biotechnology and pesticides: recent understandings and implications for risk communication. American Entomologist 46: 8-16.

Peterson, R.K.D., and L.G. Higley (1993). Communicating pesticide risks. American Entomologist 39(4): 206-211.

Vestal, T.A., and G.E. Briers (2000). Exploring knowledge: attitudes and perceptions of newspaper journalists in metropolitan markets in the United States regarding food biotechnology. Journal of Agricultural Education 41(4): 134-144.

Wolt, J.D., and R.K.D. Peterson (2000). Agricultural biotechnology and societal decision making: the role of risk analysis. AgBio Forum 3(1): 39-46.

Zechendorf, B. (1994). What the public thinks about biotechnology. Biotechnology 12: 870-875. DOI: 10.1038/nbt0994-870. 